\title{
The Battle for Channel 7: A Media Showdown in Waterloo
}

\author{
DAVID F. MCCARTNEY AND GRANT PRICE
}

WATERLOO, IOWA, in 1953 was a bustling industrial town of 65,000 people, a manufacturing, meatpacking, and trading center for a prospering slice of post-World War II America. Growth had come swiftly: in the twenty years following the 1929 stock market crash its population swelled by nearly 50 percent. According to the U.S. Census Bureau, the number of residents in Waterloo, nearby Cedar Falls, and surrounding Black Hawk County surpassed 100,000 in $1950 .{ }^{1}$ The town's two largest employers-John Deere, the tractor manufacturer, and Rath Packing Company, the meat processor-enjoyed considerable, if erratic, expansion. Waterloo's fortunes rose and fell with the prices of grain and livestock commanded by farmers and meat producers in neighboring counties, and seasonal factory employee layoffs frequently disrupted local livelihoods. Despite the often fickle economy, however, the overall economic growth of Iowa's fifth-largest city in the early 1950s led its residents, like those in many U.S. communities, to expect rising living standards and expanded delivery of goods and services. The belated arrival of television in Waterloo epitomized this change.

A new and tantalizing medium, television's rarity fueled its allure. Americans saw one of their first public demonstrations of television at the 1939 New York World's Fair, though few had

1. U.S. Bureau of the Census, World Wide Web site, <http://www.census.gov/ population/cencounts/ia190090.txt>, 2 June 1999.

THE ANNALS OF IOWA 59 (Summer 2000). (C) The State Historical Society of Iowa, 2000. 
receiving sets yet. One year later, WMT radio in Cedar Rapids introduced television to Iowans with an exhibit at the 1940 AllIowa Fair. World War II postponed television's arrival in American homes, as the demand for raw materials and technology shifted from domestic consumers to the war effort. ${ }^{2}$

As television expanded after World War II, signals in urban areas often interfered with one another, resulting in an annoying "venetian blind" effect on the small screen. In 1948, to address complaints of excessive interference in urban television reception, the Federal Communications Commission (FCC) placed a moratorium on the issuance of new television broadcasting licenses. During the four-year freeze, the FCC gradually reduced or eliminated interference in urban areas, but lack of service remained a problem in many parts of the United States, particularly its rural areas. Nationally, farm dwellers were the last group to come within range of television due to a lack of signal accessibility. A 1952 mail survey of three hundred farm families subscribing to Successful Farming magazine found that among the 22 percent who then owned television sets, the average distance from the nearest station was 43 miles. $^{3}$

The situation was even bleaker in Waterloo, where some residents erected tall towers on rooftops, aiming antennas at two distant cities, each a hundred miles away, hoping to view Milton Berle, Howdy Doody, or even test patterns. Reception of Iowa's only two stations until the autumn of 1953-WOI in Ames and WOC in Davenport-was poor. Frustrated Waterloo viewers were eager to enjoy network and local programs from the city's own television service. Two hometown businessmen, each described by colleagues as proud, willful, and stubborn, were determined to launch stations. The FCC, however, allotted only one VHF channel to the Waterloo area, and both men set

2. Curtis Mitchell, Cavalcade of Broadcasting (Chicago, 1970), 152; Channel Two Celebrates 40 Years Together, Guy Gannett Broadcasting, Cedar Rapids, 1993, videotape; Leo Bogart, The Age of Television: A Study of Viewing Habits and the Impact of Television on American Life (New York, 1958), 8.

3. Michael D. Murray and Donald G. Godfrey, eds., Television in America: Local Station History from Across the Nation (Ames, 1997), 172-73; Bogart, Age of Television, 10, 16. 
their sights on that channel. As it turned out, in the parlance of the Old West, the town wasn't big enough for the two of them.

In the hot summer of 1953, an Iowa version of High Noon got under way in U.S. District Court-the battle for Waterloo's Channel 7. As in the film, only one man was destined to win. However, unlike Will Kane, the town marshal portrayed by Gary Cooper in the 1952 epic, both Waterloo men enjoyed the support of friends and townspeople willing to take sides in an increasingly bitter contest of will, personal ego, and community leadership.

The television channel licensing contests of the early 1950s were, at times, rambunctious and roughshod, somewhat akin to the chaotic Oklahoma land rush of 1889 or the more recent dotcom races to secure exclusive Internet domain names. ${ }^{5}$ The outcomes of these license disputes, which sometimes reached the FCC in Washington as contested hearings, determined the direction of media ownership and control in scores of communities for years, even decades, to follow. At stake were investments, careers, and prestige, as well as the privilege and power to determine potentially influential television programming in a media landscape populated by only a few channels in each locality. Throughout the United States, competing would-be television broadcasters vied for public support, lobbied for preferential treatment by the FCC, and even resorted to questionable or illegal tactics to win a coveted license. ${ }^{6}$ Few such disputes,

4. "Table of Assignments: Part II, Final TV Report," Broadcasting-Telecasting, 14 April 1952, 133. The FCC issued this table, outlining television channel assignments for cities throughout the U.S. and its territories, after its four-year study of television's technical characteristics and population demands for local service, factors that mandated limits on the number of television stations permitted to operate without interfering with one another.

5. The weekly industry publication Broadcasting-Telecasting confirms that between mid-1952 and 1954 the FCC's docket was crowded with contested hearings. By 1955, the number of scheduled hearings declined as the majority of the "first generation" of television license grantees had been resolved.

6. Scholarly literature chronicling this largely unknown but critical aspect of U.S. telecommunications history is sparse, confined primarily to popular press and trade publication accounts of the time. And most of the literature that is available concerns the development of television on a national level. An exception is one recent title, the previously cited Television in America: Local Station History from Across the Nation, which recounts the experiences of selected local television station founders, organized by region. However, little discus- 
however, were as well documented, acrimonious, or eccentric as the clash between Waterloo broadcasters Joel "Joe" DuMond of KXEL and Ralph J. McElroy of KWWL. Their conflict never reached the halls of the FCC, however. Instead, it was finally settled when the two men went for a ride in a car one summer evening, after McElroy, the underdog in the standoff, outmaneuvered his prestigious rival in a federal courtroom in Iowa.

IN THE EARLY 1950s, commercial television was still in its infancy, with many station operators facing financial losses despite growing revenue from advertising sales. Even in large cities where scheduled television broadcasts began prior to World War II, many stations were not yet profitable. As new licensees soon learned, the costs of maintaining and operating a television station far exceeded those of radio, due to high labor expenses, greater program production demands, and special equipment needs. Financial investors with deep pockets sustained the new medium in its early years. According to one trade journal, up to one-third of the newly built stations in 1953 could expect losses due to operators' inexperience and naiveté. "No Jackpots for Poorly Planned Stations," read the headline.

Investing in television was risky, but its future was full of promise. At the close of the war in 1945, fewer than seven thousand sets were in operation in the United States, and only six stations were broadcasting a regular schedule of programs. By January 1950, less than five years later, 99 stations were broadcasting to more than four million sets nationwide. "Television is young, fluid, and unpredictable," said Oscar Katz, director of CBS's Division of Research, in 1949, marveling at the rapidity of television's growth and the public's clamor for television to

sion addresses the circumstances under which certain licenses were granted when two or more parties petitioned the FCC for a single available frequency. These contested hearings sometimes delayed television service to unserved areas while the FCC's commissioners considered the relative merits and weaknesses of each of the competing applicants before granting licenses.

7. Television Digest, 24 October 1953. See also Christopher H. Sterling and John M. Kittross, Stay Tuned: A Concise History of American Broadcasting, 2d ed. (Belmont, CA, 1990), 271, who note that many early television operators were shocked and dismayed to discover that it generally cost ten times as much to operate a television station as it did a radio station in the same locality. 
bring the world to its doorsteps. David Sarnoff, chairman of the board of RCA, the parent company of NBC, was enthralled: "So swiftly that America has barely awakened to its significance, television has reached from city to city across the nation. It has brought into millions of homes the magic of its immediacy and reality-transmissions of sight and sound combined, with an impact on practically all phases of life." ${ }^{\prime 8}$

Radio broadcasters were at once wary of and enthusiastic about the accelerating development of the new medium. In 1950 nearly 77 percent of all commercial television applicants in the United States were affiliated with a radio station, insurance of a sort by anxious radio broadcasters should the new medium's popularity eclipse the old. The radio executives' fears were justified: on average, radio listenership declined by 43 percent in cities with television in 1950. Radio station managers looked frantically for answers to stanch their ratings hemorrhage. Ted Cott, manager of New York City's WNBC radio, visited Portland, Oregon, a city still without local television service in 1951 . There, at a radio programming conference, he told his colleagues, "You have not quite felt the intensity and the push and the real devastation of the impact of television yet. In New York we have a very serious problem. We have lots of trouble. This competition is very debilitating." Paradoxically, overall revenue from $\mathrm{AM}$ radio stations continued to rise nationally during this period, despite declining listenership in some cities and the decline by 1950 of network radio's prominence. ${ }^{9}$

Over time, reports of radio's death proved to be greatly exaggerated, of course. In 1951, however, no one could accurately predict the extent of television's impact on the broadcasting industry or, for that matter, its immeasurable impact on American life. Television's growth was swift in the 15 years following

8. Charles Arthur Siepmann, Radio, Television, and Society (New York, 1950), 317-18; Walter B. Emery, Broadcasting and Government: Responsibilities and Regulations (East Lansing, MI, 1971), 149.

9. Siepmann, Radio, Television, and Society, 326, 341; Ted Cott, "Building Station Personality," audiotape of lecture presented at conference sponsored by Broadcast Music, Inc., Portland, Oregon, 24 July 1951, BMI Program Clinic Collection, Library of American Broadcasting, University of Maryland at College Park; Sterling and Kittross, Stay Tuned, 270. 
World War II, affecting all aspects of leisure patterns. ${ }^{10}$ Television's early financial uncertainties notwithstanding, the proliferation of new stations and soaring public enthusiasm sent a sobering message to many radio executives: jump into television or miss out. Joel "Joe" DuMond and Ralph J. McElroy, managers of competing Waterloo radio stations, understood this perfectly in 1953, when McElroy's company sued DuMond's, alleging conspiracy, restraint of trade, and other offenses. At stake, ultimately, was the right to broadcast on channel 7.

DuMOND AND McELROY came from very different backgrounds, but their careers in broadcasting began at the same Iowa radio station. DuMond, born in Finchford, Iowa, on November 21, 1898, moved with his family to nearby Waterloo when he was seven years old. After graduating from East High School, he attended the University of Iowa and Iowa State Teachers College. He studied music and voice under Charles Dalmores of the Chicago Opera, performed on the traveling Chautauqua circuit, and, throughout his life, composed about 60 hymns, his favorite being "By the Bend of the River." In 1928, at age 29, DuMond debuted as a singer, pianist, and accordionist on WMT radio, when the station was based in Waterloo. Graced with a rich baritone voice, the young man created and portrayed the character Josh Higgins of Finchville, a fictional Iowa pioneer, regaling his listeners with tales of growing up on a farm in rural Black Hawk County. To entertain his audience, he relied heavily on his and other local residents' artistry to sustain WMT's demanding schedule. He was also an adept talent scout. His "discoveries" included broadcast personality Fran Allison, a native of nearby La Porte City. First appearing on WMT as gossipy Aunt Fanny about 1934, her career later flourished as hostess of the acclaimed Kukla, Fran, and Ollie show on NBC television in the 1950s. ${ }^{11}$

10. Sterling and Kittross, Stay Tuned, 312.

11. "Autobiography of Joel Harvey DuMond Sr.," DuMond Family Page, World Wide Web site, <http://www.inconnect.com/ bdi/roots_branches/DuMond. html>, 18 March 2000; Waterloo Courier, 6 December 1990; Dorothy Ehr Chamberlin, interview by Grant Price, Waterloo, 1997, videotape recording, Archives of Iowa Broadcasting History, Wartburg College, Waverly; Carol Hughes, 
"He was a very gracious man," recalled Dorothy Ehr Chamberlin of Waterloo, "[and] he played the accordion beautifully." Chamberlin, a former singer, recalled DuMond's elegant manners when she and friend Florence Peiffer arrived for their WMT debut in 1928 as The Air Harmony Twins. At a time when almost all radio programming was live, DuMond further refined his Josh Higgins persona, bringing fame to the man from Finchford. At the same time, as the station's program production manager, he received valuable mentoring from pioneer Iowa broadcaster Harry Shaw. From WMT, DuMond moved to a Chicago radio station, then to NBC radio's popular National Farm and Home Hour in the mid-1930s, where Josh Higgins enjoyed national renown during the golden age of radio. In tribute to his birthplace, DuMond even broadcast live, coast-to-coast, from Finchford on August 26, 1937, prompting Governor Nelson Kraschel to proclaim "Josh Higgins Day" in honor of Iowa's pioneers. ${ }^{12}$

In 1939 DuMond and his family moved back to Iowa. In Burlington he established, then managed, KBUR radio for two years. Eager to return to his home town, DuMond established a new radio station in Waterloo in 1942. Since WMT had moved its main studios and offices to Cedar Rapids in 1935, Waterloo had had no locally based station, although WMT continued to maintain an auxiliary studio there. With the help of influential contacts at the FCC, DuMond's dream came true: his own 50,000watt radio station. KXEL, "The Voice of Agriculture," was licensed to the Josh Higgins Broadcasting Company, the last radio station to debut in the United States until the end of World War II. ${ }^{13}$ The station's clear-channel signal covered much of Iowa and parts of three other states by day and reached from the Rockies to the eastern seaboard by night. Things were "look[ing] mighty good at KXEL . . . in Ioway," as one of DuMond's advertisements exclaimed in $1946 .{ }^{14}$

\footnotetext{
"Kukla and Ollie's Real-Life Heroine," Coronet Magazine, October 1951 $<$ http://www.ultinet.net/ kfo/coronet.html>, 19 June 2000.

12. Chamberlin, interview; Waterloo Courier, 4 December 1990, 17 August 1970.

13. KXEL radio premiered on 1540 kilocycles on July 14, 1942. Between 1942 and 1945, the FCC suspended issuing new licenses because of the war.

14. Jack Alicoate, ed., Radio Annual (New York, 1946), 400.
} 


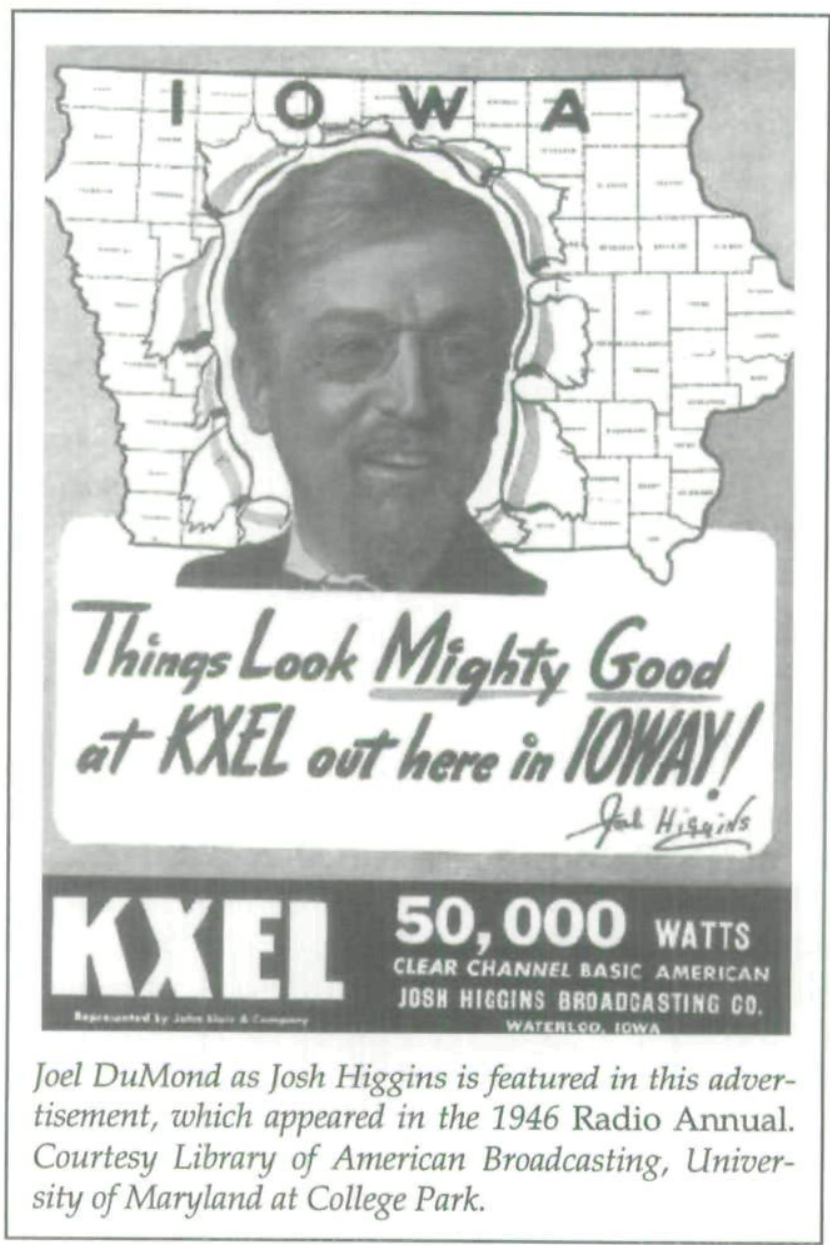

UNLIKE DuMOND, who started early in radio and rose quickly to celebrity status as an entertainer, Ralph J. McElroy took a rockier road to media prominence. Born on March 6, 1910, in Eau Claire, Wisconsin, he dropped out of school as a teenager, left a difficult family life, and ended up in radio by happenstance. His first job was with an F. W. Woolworth variety store in Minnesota as a stock boy. By age 22, he was transferred to Cedar Rapids, where he was the downtown store's assistant manager. Downtown Cedar Rapids was also the site of Art Shepard's 
popular man-on-the-street interview program on WMT radio, and McElroy was a frequent guest on the show. He had no radio experience, but on bad-weather days when it was difficult for Shepard to stop passersby and talk, the garrulous McElroy was only too happy to oblige. McElroy's gift of gab won the attention of William B. Quarton, then president and general manager of WMT, who rewarded the young shopkeeper in 1935 with his own daily man-on-the-street broadcast in Waterloo, where WMT continued to operate an auxiliary studio. There, McElroy honed his radio announcing and sales skills. ${ }^{15}$

R. J. McElroy, as he was better known, became WMT's top advertising sales representative. Warren Mead, a longtime colleague, recalled McElroy's supreme self-confidence. He liked to play golf, and he would "simply take off when he pleased," Mead said. When the sales manager would "call him on the carpet, Mac would simply say, 'Okay, fire me and get someone else who can sell as much as I do.."'16 McElroy was never fired; indeed, he was promoted to Waterloo sales manager by 1945 . Following his service in the U.S. Army during World War II, however, WMT phased out its auxiliary Waterloo studio and office, consolidating all of its operations at its main Cedar Rapids location by 1946 .

Rather than move with WMT to Cedar Rapids, McElroy decided to start his own radio station in Waterloo. Following WMT's Waterloo studio closure, he raised a modest $\$ 45,000$ from a group of local businessmen, and on November 2, 1947, 1,000-watt KWWL signed on; five years after Joe DuMond's 50,000 -watt station premiered, and with a mere 2 percent of the power. ${ }^{17}$ Several years had separated their careers at WMT, but McElroy and DuMond's paths were about to cross at last.

15. Waterloo Courier, 16 February 1965.

16. Warren Mead, Black Hawk Broadcasting: The McElroy Years (Waterloo, 1977), 4.

17. Papers of the Black Hawk Broadcasting Company, Archives of Iowa Broadcasting History. In addition to the Warren Mead booklet and the Waterloo Courier obituary cited above, McElroy's life story is told in a book commissioned by the R. J. McElroy Trust: Robert Neymeyer, R. J. McElroy: A Biography (Waterloo, 1997). 
JOE DuMOND, with his recent fame as a network radio star, his launch of 50,000-watt KXEL, and his flair for promotion, was an imposing presence in Waterloo during the 1940s. He drove a Jaguar, raised Tennessee walking horses as a hobby, and cultivated prominent friends in the business and political communities, both in Waterloo and in Washington, D.C. ${ }^{18}$ A state park near Cedar Falls was even named in honor of his character, Josh Higgins. ${ }^{19}$ With advertisers looking for places to spend their money during the war years, he and his station prospered. WMT radio in Cedar Rapids remained northeastern Iowa's most popular station, but by 1948 KXEL was ranked eighth among more than 40 radio stations statewide as "listened to most in Iowa," a significant accomplishment for a station on the air less than six years. ${ }^{20}$

Trouble lay ahead, however. Following World War II, the FCC lifted its wartime suspension of radio station licensing. It also resumed issuing licenses for the new medium of television, which had been stopped in its infant tracks when the United States entered the war. By 1948 KXEL no longer had the Waterloo-Cedar Falls playing field all to itself. It was now competing with two new local radio stations: McElroy's KWWL, licensed to the Black Hawk Broadcasting Company, and 1,000-watt daytime-only KAYX, which had also signed on in 1947. KXEL dwarfed both stations in terms of power, prestige, and experience, so perhaps at first DuMond took neither station very seriously, either as radio competitors or as competing television applicants.

18. According to FCC records quoted in R. J. McElroy's affidavit filed in Black Hawk Broadcasting Company's antitrust suit, DuMond's local supporters included nearly 20 stockholders of his broadcast company, of which he was majority owner. Among the outside stockholders was Horace L. Lohnes, a prominent Washington, D.C., communications attorney. Ralph J. McElroy, sworn affidavit, Case 658 Civil, Black Hawk Broadcasting Company v. Josh Higgins Broadcasting Company, U.S. District Court for the Northern District of Iowa, filed 6 July 1953, Federal Records Center, National Archives and Records Administration, Kansas City, Missouri.

19. Today, the park is known as George Wyth State Park. See CedarNet World Wide Web site, <http://www.cedarnet.org/tour/149.html>, 18 March 2000.

20. Dr. F. L. Whan, Iowa Radio Audience Survey (Wichita, 1948), 20. 


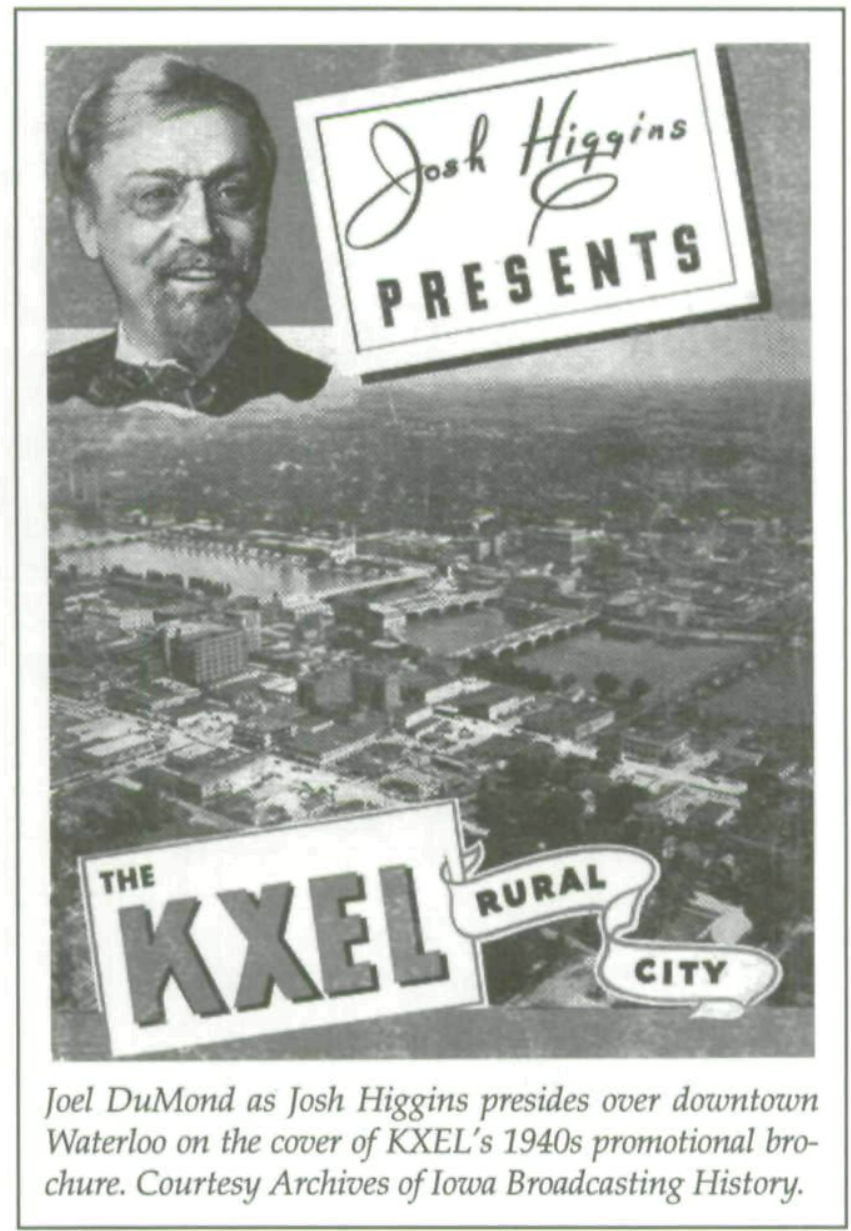

KAYX proved inconsequential, never ranking higher than fourth place in Black Hawk County audience ratings, behind KXEL, WMT, Des Moines's WHO, and, after 1949, KWWL. ${ }^{21}$ With new management, KAYX's call letters changed to KBOK in 1951. The station remained in fifth place and in 1953 was sold to a Minneapolis-based religious institution as a noncommercial operation. $^{22}$

21. Ibid. (1948-1950), 92.

22. Broadcasting Yearbook (New York, 1955), 146. In 1953 KBOK was sold to Northwest Bible Institute of Minneapolis (now Northwestern College). Its call letters were subsequently changed to its present KNWS. 


\section{FIGURE 1}

BLACK HAWK COUNTY, IOWA, RADIO STATIONS "HEARD REGULARLY"

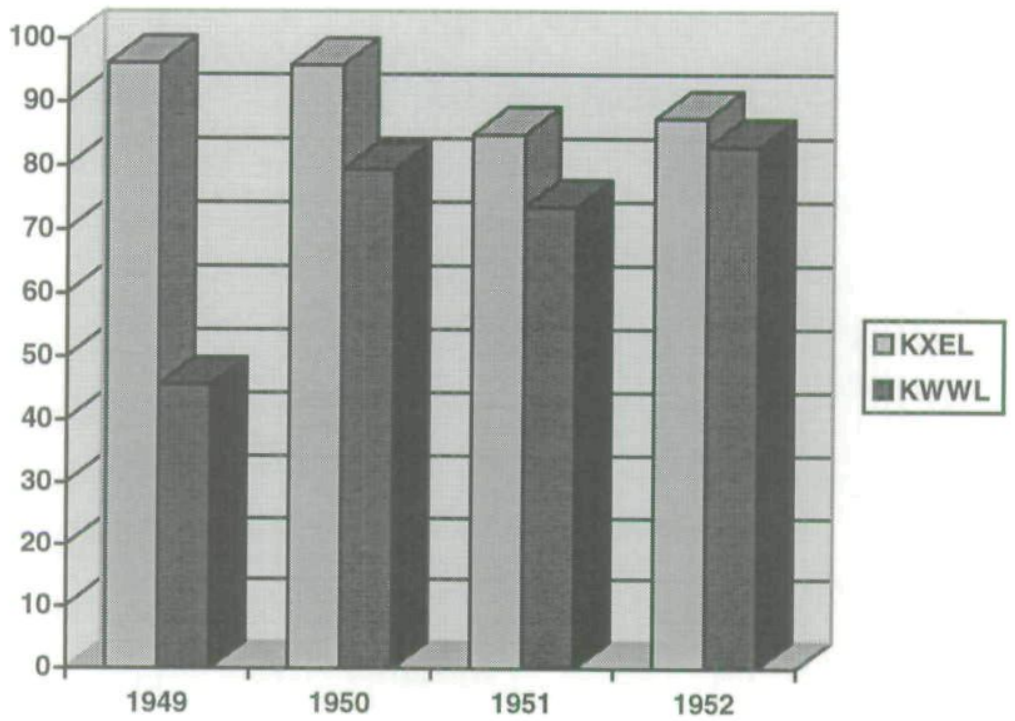

SOURCE: Dr. F. L. Whan, Iowa Radio Audience Survey (Wichita, 1949-1952).

KWWL, by contrast, was an upstart endeavor for McElroy and his associates. From 1947 to 1953, the size of its staff nearly tripled, from 12 to 35, and its ratings war with KXEL escalated sharply. In 1949, according to a survey of Black Hawk County listeners, KXEL ranked first among stations "heard regularly," polling over 96 percent. KWWL ranked fifth with only 45 percent. By 1952, however, KWWL was closing in fast, ranking second to KXEL, 87 to 83 percent (see fig. 1). ${ }^{23}$

More dramatic were the responses of Black Hawk County listeners when asked which particular station they "listened to most," as opposed to which stations they "heard regularly." By this definition, KWWL's audience increased nearly tenfold between 1949 and 1952, rising from fifth to second place among local listeners. KXEL, while retaining first place during the four-

23. Whan, Iowa Radio Audience Survey (1949-1952), 93. 
FIGURE 2

BLACK HAWK COUNTY, IOWA, RADIO STATIONS "LISTENED TO MOST"

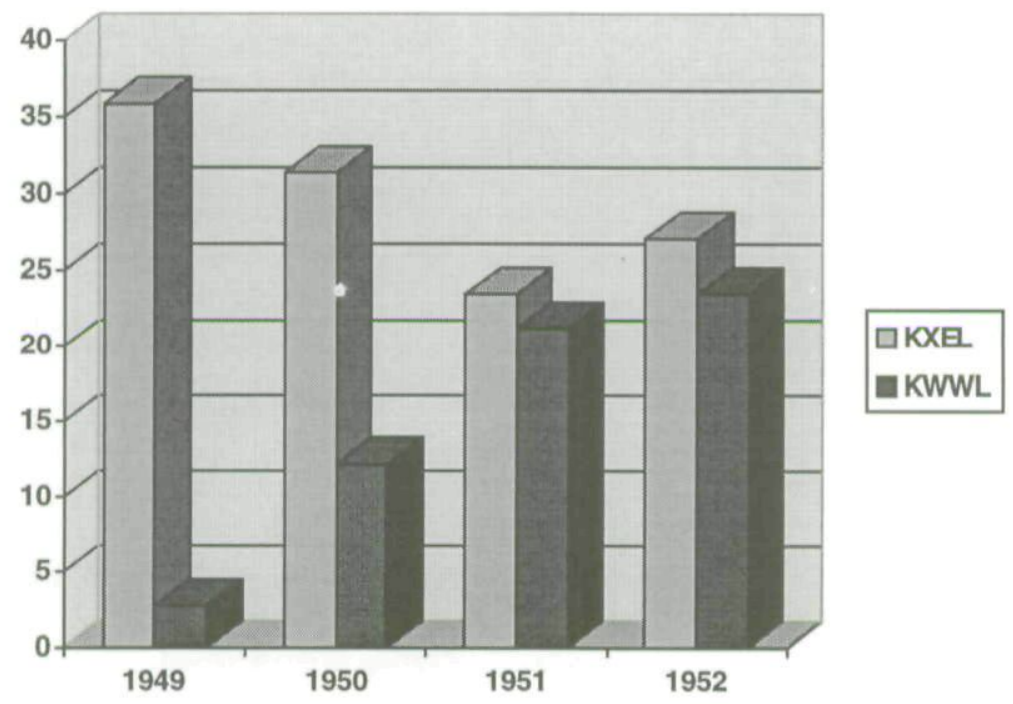

SOURCE: Dr. F. L Whan, Iowa Radio Audience Survey (Wichita, 1949-1952).

year period, saw its audience share generally erode (see fig. 2). ${ }^{24}$ KXEL's audience decline may have been due in part to the proliferation of other radio stations during this period. With more signals competing for roughly the same number of listeners, a given station's share of the audience normally decreases or, at best, remains constant. KWWL's ratings, however, grew steadily during the four-year period.

Despite its comparatively low power, KWWL radio also attracted enough listeners to rank it among the upper quarter of stations "most listened to" statewide by 1952. It rose from unranked as late as 1950, to 18th out of 90 in 1952. KXEL, meanwhile, maintained its eighth-place ranking in the state, behind such entrenched favorites as WHO, WMT, WOW in Omaha, KGLO in Mason City, and KMA in Shenandoah. ${ }^{25}$

24. Ibid. (1949), appendix 16; ibid. (1952), 93.

25. Ibid. (1950), 26; ibid. (1952), 53. 
Changes in national radio trends during this time may help explain KWWL's ascendancy and KXEL's stagnation in listenership. Following World War II, radio changed from a national to a local advertising medium, placing new emphasis on local news and local personalities, or "disc jockeys." Network radio diminished greatly by 1950, losing much of its prized entertainment talent-and revenue- to television. Sports and hourly newscasts became network radio's new staples of programming. KWWL, among the new generation of postwar local radio services, capitalized on this new philosophy, tailoring its local schedule around the Mutual network's newscasts, sports, and features. Gone or disappearing from radio were drama series, soap operas, and other elaborate productions. ${ }^{26}$

KWWL's dedicated staff was also responsible for the station's early success. McElroy hired a capable journalist, Ed Falk, as his news director, and Warren Mead as his program director. Mead, well educated and urbane, complemented McElroy's rough-and-tumble personality. Together, the three men forged a strategy to bring community service and a strong local identity to Waterloo radio. McElroy, like his competitor DuMond, also understood the value of friends in influential places. He enlisted some of the town's leading business and professional figures to invest in the new enterprise and to serve on his board of directors. Among them was Waterloo attorney Robert Buckmaster, a rising legal star who would become a key figure in KWWL's bold challenge to KXEL's plans for television.

AT THE END OF WORLD WAR II, the FCC resumed licensing television stations. In less than three years, however, the commission recognized a host of unexpected problems resulting from television's rapid expansion. Viewers in urban areas complained of interference from an abundance of stations,

\section{Sterling and Kittross, Stay Tuned, 270.}

27. Ralph J. McElroy, sworn affidavit. In addition to Buckmaster, other prominent community members who served on Black Hawk Broadcasting Company's board of directors included R. A. Rath, director and chairman of the board, Rath Packing Company; Vivian Johnson, president, First National Bank of Cedar Falls; R. L. Penne, president, National Bank of Waterloo; and Robert J. McCoy, editor and general manager, Waterloo Daily Courier. 
while rural residents received little or no television reception at all. The twelve very-high-frequency (VHF) channels established by the FCC proved to be an insufficient number for signalcongested cities. The FCC was attempting to accomplish several tasks at once, some of which seemed contradictory: ensuring "rapid, efficient nationwide service," guaranteeing that the new television licensees would serve the public interest, and protecting technical quality with ever-changing standards among the numerous manufacturers of transmitters and receiving sets. ${ }^{28}$ Accomplishing all of these goals simultaneously was a formidable challenge.

Clearly, the commissioners decided, something had to be done to calm the chaos. In June 1948, the FCC ordered a moratorium on all new television station applications. The moratorium was to remain in effect until the agency resolved the problems. Intended as a brief, temporary action, the "freeze," as it became known, was enforced for nearly four years, from September 30, 1948, to April 14, 1952. During that time, hundreds of television license applications, including KXEL's, were left in the cold. The moratorium slowed the development of television, especially in rural areas, but it did permit the federal government to reallocate channels in localities, review available frequencies for possible channel expansion, and create a blueprint of technical and public service standards for the new medium. ${ }^{29}$

After a long and complicated review, the FCC devised a national table of channel allocations to clear the airwaves' congestion. $^{30}$ The table was based on engineering studies that identified maximum signal reception areas for each available channel. While the FCC granted multiple channels to large cities, it also, for the first time, guaranteed channels in less populated areas. To reduce signal interference while permitting a greater number of licensees, the FCC also added 70 ultra-high-frequency (UHF) channels, despite their technical inferiority to VHF. Broadcasters were justifiably skeptical whether viewers would accept the hard-to-tune UHF apparatus. In the early 1950s UHF channel

28. Emery, Broadcasting in America, 40, 45, 233.

29. Siepmann, Radio, Television, and Society, 319.

30. Emery, Broadcasting in America, 150; "Table of Assignments." 
selection required skillful fine-tuning, while VHF selection required only the simple click of a knob. Additionally, receiving a UHF signal was more costly to viewers because of the necessary special antenna and converter equipment. Few broadcasters, certainly not DuMond or McElroy, were willing to invest in UHF equipment if a VHF channel were available in the same locality.

In early 1951, while the freeze was still in effect, the FCC released its first draft of allocated channels, proposing VHF channel 7 and UHF channel 16 for Waterloo. The decision was still far from final, however. When the agency sought comments from would-be licensees, KWWL, using its own engineering studies, suggested that the FCC add VHF channel 12, along with channels 7 and 16, for Waterloo. Adding channel 12, KWWL argued, would not only be technically feasible and beneficial for the community, but would also avoid a lengthy contest for the sole VHF channel 7, allowing both potential competitors to telecast on comparable channels. KXEL, for its part, did not object to the FCC draft plan for the one VHF channel 7 . $^{31}$

Meanwhile, despite the freeze and a 1949 FCC order to the contrary, KXEL, on March 19, 1951, applied for the still tentative channel $7 .{ }^{32}$ KXEL's action alarmed KWWL. Sensing that it had no choice but to do the same, KWWL, on December 21, 1951, filed its own application to broadcast on channel 12, should it become available. ${ }^{33}$

At last the freeze ended in the spring of 1952. The FCC's long-awaited channel allocation table, announced on April 14 as the "Sixth Report and Order," affirmed what the agency first proposed for Waterloo: VHF channel 7 and UHF channel $16^{34}$ (Channel 12 was eventually designated a noncommercial, educational channel for Iowa City.) With Black Hawk Broadcast-

\section{Ralph J. McElroy, sworn affidavit.}

32. On July 11, 1949, about 10 months after the freeze began, the FCC declared that no further license applications for television were to be filed until after the commission released its final table of television channel allocations. The final table was not announced until April 14, 1952, more than one year after KXEL prematurely filed its application.

33. Ralph J. McElroy, sworn affidavit.

34. "Table of Assignments." 
ing's channel 12 idea officially scrapped, and with KXEL's application pending, KWWL filed an amended application for channel 7 on July 7, 1952. The race for Waterloo television officially moved to Washington. At home, however, the dispute grew nastier.

JOE DuMOND perhaps viewed his attempted venture into television not only as his responsibility, but as his right, given his experience, his position in the community, and the resources of his successful radio station, which by 1952 included Waterloo's only FM service. In February 1952, with the licensing freeze still in effect, DuMond presumptuously started to build a television facility about two miles east of Waterloo on US Highway 20. According to a local newspaper account, the KXEL "radio and television center" would be ready for operation about June 1, 1952, pending the issuance of an FCC permit, "which it is expected would require 30 days following application." ${ }^{35}$

Confident that the FCC would grant his company the license, DuMond moved his AM and FM radio stations into the new building in December 1952. In a lavish, double-page newspaper advertisement in the Waterloo Courier the day after Christmas, he proudly announced the opening of the "ultra modern Josh Higgins Radio and Television Center. ${ }^{\prime 36}$ With studio sets constructed for local live telecasts, including a kitchen for a cooking show, "KXEL-TV" was poised to premiere. Weary of fuzzy, distant reception, northeastern Iowans, and especially DuMond, were ready at last for local, clear-reception television. All "KXEL-TV" needed was its license. There were two small details, however.

First, FCC rules required a construction permit before a broadcast facility was built, and KXEL had no such permit for television service. Congress had adopted the rule in 1934 for political, technical, and economic reasons. Legislators thereby sought to free the FCC from pressure to grant licenses to zealous applicants who had already invested heavily in broadcast equipment without proper authorization, and they wanted to ensure proper

35. Cedar Falls Daily Record, 15 February 1952.

36. Waterloo Courier, 26 December 1952. 


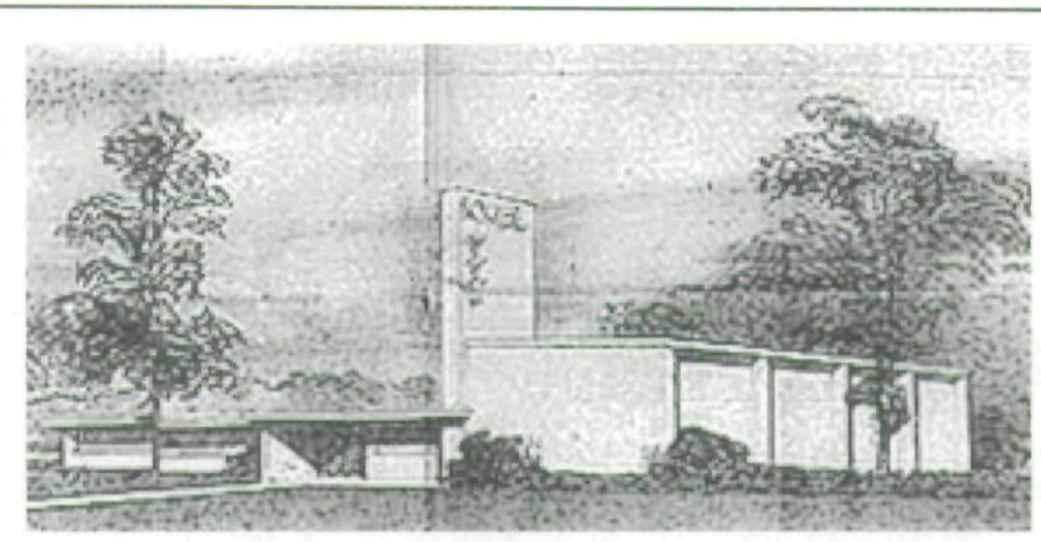

To celebrate its tenth anniversary, KXEL published an advertisement in the June 17, 1952, Cedar Falls Daily Record, with this sketch of what it labeled Josh Higgins' Radio-Television Center. "KXEL's ultra-modern studios," the ad proclaimed, "will represent the ultimate in both radio and television facilities." Courtesy Archives of Iowa Broadcasting History.

station construction in accordance with FCC regulations. Congress also intended to protect investors from committing their money to hard-to-liquidate broadcast equipment should a license not be granted. ${ }^{37}$

Second, R. J. McElroy's Black Hawk Broadcasting Company applied for the channel 7 license on July 7, 1952, five months after construction of KXEL's Josh Higgins Radio and Television Center had begun. To DuMond, McElroy's application following the lifting of the freeze only muddied the waters, guaranteeing a lengthy contested FCC hearing for the license and the prospect of yet another long delay in television service to the area. DuMond believed it was finally possible to bring television to Waterloo; McElroy's application, however lawful, only jeopardized DuMond's opportunity.

McElroy's decision to apply for the channel 7 license prompted DuMond to embark on a campaign of public pressure in Waterloo and Cedar Falls. The campaign, including speeches, petitions, and threats to boycott KWWL radio advertisers and stockholders, lasted more than a year. Affidavits filed

37. Emery, Broadcasting in America, 271. 
in Black Hawk Broadcasting's lawsuit later recounted numerous activities during 1952 and 1953 that were, according to McElroy, intended to impair KWWL's business and to force it to withdraw its application by "threat, intimidation, boycott and the circulation of false and defamatory statements. ${ }^{\prime 38}$

DuMond's plan to sway public opinion in his favor began in earnest shortly after KWWL announced its intent to apply to broadcast on channel 7. In June 1952 DuMond took to the KXEL microphone, spiritedly describing progress on construction of his company's new radio and television center and challenging "those who would delay television service to you." Because KWWL had applied for "the same channel which KXEL is prepared now to utilize," he said,

we must, according to the Federal Communications Commission, undergo a long, expensive hearing. ... The delay might well run two years, and cost from 30 to 50 thousand dollars. To avoid this delay . . . I publicly challenged [KWWL] last week to forgo the hearing, and according to the existing FCC rules, submit their application along with that of the Josh Higgins Broadcasting Company, and leave the entire decision to the members of the Commission. ... Such action would be unquestionable proof of a desire to honestly serve the public.

Have I heard a reply to that challenge? Indeed not. And I regret to state that I do not expect a reply, so long as certain interests dominate.

DuMond thus suggested that he, and not his competitor, was acting in the public interest by laying a claim to channel 7 . He closed his broadcast with a tempting thought: If the FCC could determine the case directly without a hearing, "I can promise you this: You would be enjoying the 1952 World Series on KXEL-TV. Thank you and good night. ${ }^{\prime \prime 39}$

The hint of a World Series telecast denied as a result of KWWL's competing application was a low blow to McElroy. DuMond's prediction of television delays in contested localities proved accurate, however. The FCC, faced with scores of contested licenses in unserved cities, did not release its list of high-

38. Ralph J. McElroy, sworn affidavit.

39. Joel DuMond, remarks broadcast on KXEL radio, Waterloo, [?] June 1952, audiotape recording, Archives of Iowa Broadcasting History. 
est priority cities for licensing action until August 24, 1953, 16 months after the freeze was lifted and more than a year after DuMond's radio remarks. Those cities were ranked in order of priority based on population, lack of service, and the presence of a contest for available channels. Using those criteria, the FCC attempted to resolve disputes in those localities as quickly as possible. Des Moines ranked first, at the time the largest city in the United States without local television service, though it was well within the signal range of Ames's WOI-TV, 30 miles away. Two applicants were competing for each of Des Moines's two available VHF channels. Waterloo, also a contested city at the time, ranked 14 th on the priority list of more than 50 cities. $^{40}$

The government could not resolve these channel disputes quickly. Even cities near the top of the FCC's priority list did not receive local VHF service for two or more years after the commission announced its priority list. WHO-TV premiered in Des Moines on April 15, 1954, eight months after the priority list was announced, but of the next three cities on the list, San Jose and Waco did not receive local VHF service until 1955, Hartford not until 1957. ${ }^{41}$ DuMond, believing Waterloo would face a similar fate, vigorously pursued a direct appeal to the commissioners, confident that the panel would rule in his favor without a hearing. He had good reason to be confident. Among his contacts in Washington was FCC commissioner Rosel Hyde, a close friend who became FCC chairman in $1953{ }^{42}$

McElroy's refusal to accept DuMond's challenge to forgo an FCC hearing aggravated an already tense climate in the tworadio-station town. From early to mid-1952, DuMond advertised and promoted his forthcoming radio and television center, purchasing billboards and other announcements heralding the soon-to-arrive "KXEL-TV." On August 1, 1952, KWWL com-

40. "FCC Readies Flexible Priority List on TV Hearing Speed-Up," BroadcastingTelecasting, 24 August 1953, 44.

41. Broadcasting and Cable Marketplace (New Providence, NJ, 1992), B3-B72.

42. Hyde was perhaps DuMond's most influential contact in Washington. He became a member of the FCC in 1946 and served as its chairman in 1953-54 and 1966-69. The two men exchanged friendly correspondence at least intermittently during this time. Rosel Hyde Papers, Mss 142, Wells Freedom Archives, Harold B. Lee Library, Brigham Young University, Provo, Utah. 
plained of the practices to the FCC. KXEL relented by removing its billboards and returning to manufacturers most of the equipment it had purchased for its television studios. DuMond, nevertheless, continued to maintain that the equipment would be available "in a matter of days" should the FCC approve KXEL's application. ${ }^{43}$

In September 1952, however, before he shipped the equipment back, DuMond hosted a tour of the new facility for area television servicemen and dealers. Along with the transmitting and production equipment, the tour featured highlights of the new building, including recessed canals to house television cables and platforms to accommodate specially located studio cameras. "It was all part of a unit for telecasting," according to Russell Rosenkrans, president of a Waterloo television servicemen's association, who attended the tour. ${ }^{44}$

Rosenkrans, proprietor of a local electronics parts, service, and appliance shop, was as eager as any northeastern Iowan to secure local television reception. His business, successful as it was, stood to benefit substantially from the new channel 7, regardless of who the licensee was. Other dealers and servicemen were growing impatient, wondering when the impasse would end.

In March 1953, one of Rosenkrans's colleagues broached an idea to break the stalemate. C. Robert Pedersen, later one of the defendants named in KWWL's lawsuit, showed Rosenkrans a list identifying Black Hawk Broadcasting's stockholders. Pedersen, secretary of the television servicemen's association and also a parts and service shop owner, told Rosenkrans that if enough residents boycotted businesses owned by KWWL's stockholders, or those that advertised on KWWL radio, perhaps the pressure would force Black Hawk Broadcasting to withdraw its application. The boycott, he said, would accelerate the start date for Waterloo television. Rosenkrans objected strongly to the idea, telling Pedersen he "would have nothing to do with it." Pedersen walked off, saying nothing. Within weeks, however,

43. Ralph J. McElroy, sworn affidavit.

44. Russell Rosenkrans, sworn affidavit, Case 658 Civil, Black Hawk Broadcasting Company v. Josh Higgins Broadcasting Company. 
Pedersen and other area merchants had collected more than thirty thousand signatures on petitions placed at three dozen business locations in Waterloo and Cedar Falls, urging Black Hawk Broadcasting to withdraw its license application. ${ }^{45}$

KWWL stubbornly pursued channel 7, but the threat of a boycott took its toll. The company, which until then had been enjoying steadily increasing advertising revenue, claimed it lost $\$ 25,000$ worth of advertising sales during the first half of 1953 , and projected a loss of $\$ 100,000$ in sales for the year beginning July 1 . While the number of KXEL's advertising accounts nearly doubled, from 140 to 260, between May 1, 1952, and May 1, 1953, the number of KWWL's accounts, despite strong audience ratings, remained at between 140 and 150 during the same oneyear period. The talk of a boycott also created a public relations problem for KWWL staff. "I [was] constantly on the defensive, explaining and answering the charges that [we were] delaying or blocking television to Waterloo," said Ed Falk, KWWL news director. ${ }^{46}$

The public pressure campaign culminated in a speech DuMond presented to the Waterloo Exchange Club at the President Hotel on April 13, 1953. In the speech DuMond again accused KWWL of willfully delaying television service to the area. He also acknowledged the boycott threat, suggesting that such pressure to induce his competitor to withdraw its application might be good for the community. "The [KWWL] proposal is strictly a paper proposal," DuMond told the audience. "They have their old building to rebuild, they have towers to put up, they have equipment to purchase, and, according to their [license] application, they indicate a certain manufacturer of equipment, and in checking with this manufacturer, they tell us that [KWWL has] not bought that equipment. So there certainly is no priority for them [to telecast] if they haven't bought it." DuMond again warned that if Black Hawk Broadcasting

45. Ibid.; Ralph J. McElroy, sworn affidavit.

46. Ralph J. McElroy, Warren Mead, and Edwin Falk, sworn affidavits. KWWL program director Warren Mead suggested that making the case that Black Hawk Broadcasting "had lost horrendous sums of money because of the boycott effort" required some creative bookkeeping. Mead, Black Hawk Broadcasting, 32. 
were to receive the license Waterloo would have to wait up to two additional years for local television service. ${ }^{47}$

DuMond was only partly correct about his competitor's proposal. While it was indeed a "paper proposal," legally it could not have been more than that. DuMond did not acknowledge that FCC rules prohibited the speculative purchase of equipment or station construction prior to government approval. Instead, he enumerated some of his own premature, pre-license commitments thus far: transmitting equipment from Du Mont Laboratories $(\$ 198,000)$, a new tower designed to house a television antenna $(\$ 30,000)$, and land $(\$ 17,500)$. In all, he said, KXEL's financial commitment would approach three quarters of a million dollars. ${ }^{48}$

Most striking of all, however, was DuMond's candid suggestion to the audience that they boycott his radio competitor. Such a tactic, he said, had worked in Austin, Minnesota, where channel 6 was merely weeks from signing on the air after its licensee successfully pressured another applicant to withdraw from the process. ${ }^{49}$

As DuMond described the community benefits of a boycott and recounted his substantial, if premature, television investments before the Waterloo Exchange Club, a tape recorder in an adjacent room captured every word he said. In what can only be described as a small-town coincidence, KWWL's board of directors also met that same day in the President Hotel-in the room next door-unbeknownst to DuMond. That afternoon, Warren Mead and Ed Falk surreptitiously strung a cord with a microphone and set up a recorder, recalled Falk, former KWWL news director. "We recorded the whole thing. ${ }^{150}$

DuMond's tape-recorded remarks confirmed what Black Hawk Broadcasting officials had suspected. With the tape locked away in a safe deposit box, KWWL's attorneys prepared

47. Joel DuMond, speech made at a meeting of the Waterloo Exchange Club, 13 April 1953, audiotape recording, Archives of Iowa Broadcasting History.

48. Ibid.

49. Ibid. Indeed, KMMT-TV in Austin, Minnesota, premiered on August 17, 1953, only four months after DuMond's statements.

50. Ed Falk, interview by Grant Price, Waterloo, 1995, videotape recording, Archives of Iowa Broadcasting History. 
a lawsuit, accusing KXEL of conspiracy, restraint of trade, and violations of FCC regulations. With that legal maneuver, $\mathrm{McEl}-$ roy moved the arena for the showdown from Washington, D.C., where his rival had political clout, to a courtroom in Iowa where DuMond's ill-conceived tactics would be exposed before a "no-nonsense" federal judge. The pivotal shift in the power struggle was about to unfold. Iowa television's High Noon had arrived.

JULY 6, 1953, was a stormy Monday in Waterloo. While lightning, hail, and high winds damaged crops and property at scattered locations throughout Black Hawk County, another storm was brewing in Waterloo's downtown Post Office Building. There Black Hawk Broadcasting Company, the licensee of KWWL, filed its antitrust lawsuit against the Josh Higgins Broadcasting Company, the licensee of KXEL. The ten-page complaint, filed in U.S. District Court for the Northern District of Iowa, named nine defendants, including DuMond. The suit charged KXEL with violating the Sherman Anti-Trust Act and sought an injunction, along with $\$ 500,000$ in triple damages. The lawsuit was prepared by two Waterloo attorneys, Robert Buckmaster and Glenn Beers, both members of the board of directors of Black Hawk Broadcasting. Summonses were served to DuMond and his station's chief engineer, Donald Kassner, shortly after 4:30 p.m. at the KXEL Josh Higgins Radio and Television Center. Within an hour, seven of the nine defendants were served at their homes or businesses. ${ }^{51}$

According to the complaint, Josh Higgins Broadcasting Company had persuaded businesses to stop advertising on KWWL by claiming that Black Hawk Broadcasting's application was deliberately delaying television service to the area. The suit also charged the defendants, including DuMond and several KXEL employees, stockholders, and local television dealers, with circulating petitions containing false and misleading statements about KWWL's application. That campaign, the complaint said, was an attempt to sway popular opinion to pressure KWWL to

51. Waterloo Courier, 7 July 1953; Return on Service of Writ, 11 July 1953, Case 658 Civil, Black Hawk Broadcasting Company v. Josh Higgins Broadcasting Company. 
withdraw its application. Finally, the suit charged KXEL with constructing a television station illegally to force the granting of a license to them in an attempt to create a broadcasting monopoly in Waterloo. Along with the complaint, the attorneys filed affidavits from McElroy, Mead, Falk, and other witnesses, recounting KXEL's activity during the months leading up to the suit. $^{52}$

Scheduled to hear the case was Judge Henry N. Graven. Although his federal district was based in Dubuque, Judge Graven often held court in Waterloo, and he lived in neighboring Butler County in the town of Greene, where he maintained his office. Appointed by President Franklin D. Roosevelt in 1944, Judge Graven presided over several "firsts" in the jurisdiction, including Waterloo's first naturalization ceremony and the first federal grand jury chosen to serve there. Judge Graven was temperate, intelligent, and intolerant of trifle, according to an acquaintance. "During December one year in the early 1950s, he scheduled a case for Christmas morning," senior Iowa District Judge Ralph McCartney of Charles City recalled. "After the attorneys who had traveled from Washington and New York objected, he agreed to postpone it-to Christmas afternoon." Judge Graven's unassuming office above a dry goods store on Greene's main street featured a wood stove and an extensive law library. "The visiting lawyers thought they were dealing with a country bumpkin. They dealt with a class-A mind instead," Judge McCartney said. ${ }^{53}$

Judge Graven set Friday, July 17, for the hearing on KWWL's motion for a preliminary injunction against KXEL to halt its activity. The trial concerning the charges, he said, would be scheduled later. The three-day hearing, including a lengthy session on Saturday, attracted standing-room-only crowds despite oppressive heat that caused one defendant, KXEL employee Donald Kassner, to faint. ${ }^{54}$

52. Case 658 Civil, Black Hawk Broadcasting Company v. Josh Higgins Broadcasting Company.

53. Waterloo Courier, 2 February 1970; Judge Ralph F. McCartney, telephone interview by David McCartney, May 1999.

54. Waterloo Courier, 21 July 1953. 
Throughout Friday and most of Saturday, testimony based on the affidavits of six KWWL officers and employees was presented, with cross-examination by attorneys representing KXEL and the individual defendants. Witnesses from KWWL recounted their frustration as they confronted increasing hostility in the community; KXEL employees and local residents named in the suit maintained that they had done nothing illegal in their quest to improve Waterloo's chances for receiving local television soon. ${ }^{55}$

Then, just before adjournment at 9:00 p.m. Saturday, a surprise enlivened the proceedings. Leo Cohrt, an attorney for KXEL, was cross-examining Warren Mead, KWWL's program director, about the effect of the controversy on KWWL's business. Cohrt asked Mead to confirm a rumor that a tape recording had been made of at least one of DuMond's speeches. Mead acknowledged that, yes, DuMond's April 13 Exchange Club speech had been tape recorded. At Cohrt's request, KWWL's attorneys produced a transcript of it. On the following Monday, the recording itself was played in the courtroom, an unusual technological event in $1953 .{ }^{56}$ For KXEL, the writing was on the wall.

Before the recording was played, however, DuMond himself was called to the stand. William A. Roberts, a Washington, D.C. attorney representing KWWL, asked him a series of questions about KXEL's new broadcast facility:

Q. Does the building as completed contain a TV studio?

A. No.

Q. TV control rooms?

A. No.

Q. Rooms for installation of TV transmitters?

A. It contains rooms that could be developed for those purposes.

Q. Rooms designed and intended for TV use?

A. There is no specific TV construction in the building.

Q. Is the building a TV station ready to go?

A. It is not. ${ }^{57}$

\section{Waterloo Courier, 19 July 1953.}

56. Ibid. Until Cohrt's cross-examination, KWWL's tape recording of DuMond was not admissible as evidence because DuMond was recorded without his consent. But because Cohrt, as defense attorney, raised the matter first, the recording gained new legal status in KWWL's case.

57. Waterloo Courier, 21 July 1953. 


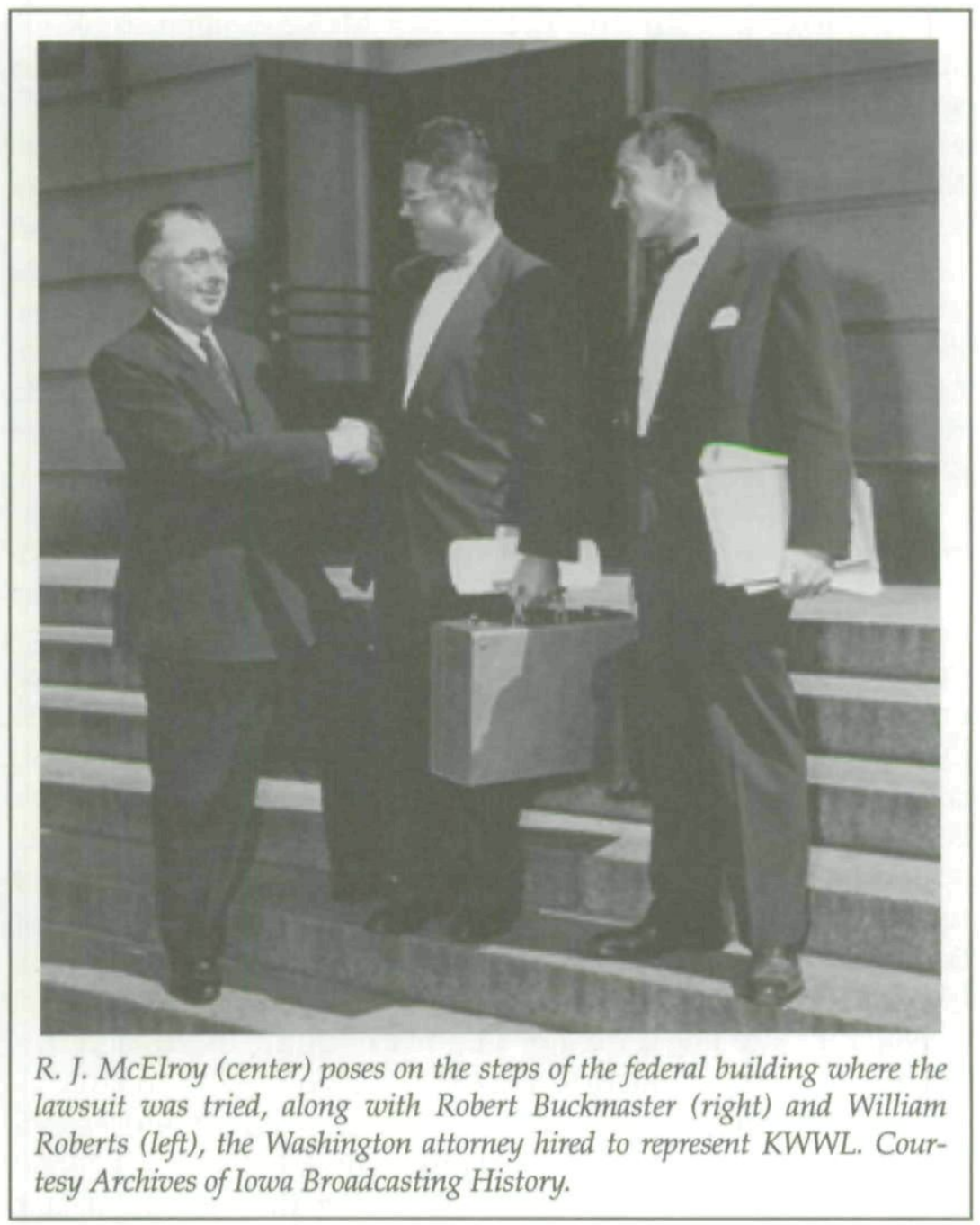

That afternoon, McElroy returned to the stand and read the FCC regulation that prohibits construction of a television station before a construction permit has been granted. He also read a communication from DuMond to the FCC in which DuMond referred to "one of our television studios." Then the court heard a tape recording of DuMond's 1952 broadcast remarks in which he made several references to the "KXEL Radio and Television Center." That evening, the court heard the recording of Du- 
Mond's Exchange Club speech. Then McElroy again took the stand to dispute some of the points DuMond had made in the speech. McElroy claimed, for instance, that KWWL had spent a total of $\$ 28,000$ on television development, as opposed to DuMond's assertion that "not one single dollar" had been paid. ${ }^{58}$

The hour was late, and McElroy had not completed his testimony when Judge Graven adjourned the hearing to August 25 , more than a month later. By the time the trial resumed on that blistering late summer day, however, the die was cast. Both tapes, particularly the one of DuMond's Exchange Club speech, confirmed KXEL's errant behavior and discrepancies between DuMond's testimony and his actions.

After the hearing, "McElroy and Joe DuMond got together and went for a ride," recalled W. Louis Beecher, a member of Black Hawk Broadcasting's board of directors. "When they came back from the ride, Joe DuMond withdrew his application, and KWWL, Channel 7, became the new tenant of the building that had been prematurely erected out east of town..$^{\prime 59}$ DuMond apparently realized that an unfavorable federal court ruling against his company was inevitable, ruining KXEL's chances to win a television license as a suitable, law-abiding applicant. In the wake of damaging evidence against KXEL for restraint of trade practices, McElroy offered to withdraw his lawsuit if DuMond agreed to withdraw his license application to the FCC. After a two-year struggle, Iowa television's High Noon culminated on a muggy summer evening, the antagonists talking it over during a ride in a car.

Joe DuMond's dream of a Josh Higgins Radio and Television Center ended abruptly. The next day, August 26, DuMond and McElroy signed an agreement ending the dispute at last. Well-heeled, 50,000-watt KXEL, for over two years a presumed television licensee, suddenly found itself out of contention to broadcast on channel 7. The two men, long stubborn and willful adversaries, finally reached an accord. DuMond agreed to lease a portion of his new building to KWWL. KWWL agreed to pur-

\section{Ibid.}

59. W. Louis Beecher, interview by Grant Price, Waterloo, 5 June 1996, videotape recording, Archives of Iowa Broadcasting History. 


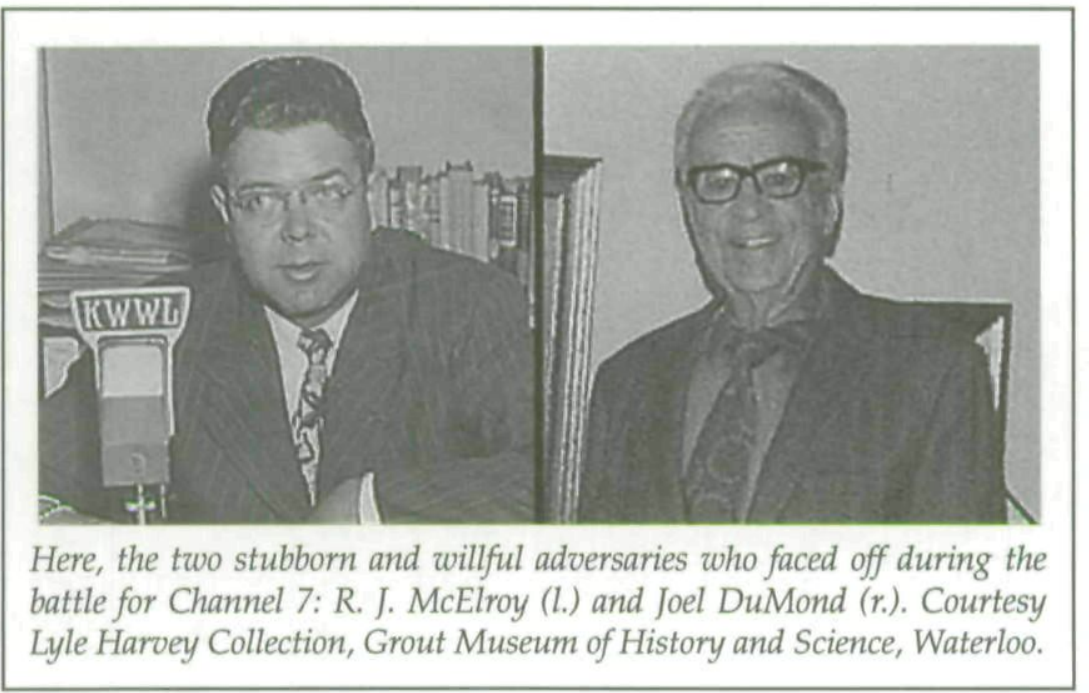

chase the antenna and tower adjacent to the building and take delivery on the television equipment KXEL had earlier arranged to purchase. Under various provisions of the accord, DuMond received about $\$ 100,000$ - one-third of his investment, at most. ${ }^{60}$

On September 26, 1953, four days before the area's first television station, WMT-TV, signed on in Cedar Rapids, Judge Graven approved McElroy's motion to dismiss KWWL's lawsuit. ${ }^{61}$ With DuMond's application withdrawn, the way was cleared for quick FCC approval of KWWL's now uncontested application for channel 7. Exactly two months later, on November 26, 1953, McElroy threw the switch and put KWWL-TV on the air, using equipment KXEL had ordered in a studio KXEL had built. Ironically, if DuMond had not ordered the equipment prematurely, KWWL-TV could not have signed on so soon.

60. KWWL-KXEL settlement contract, unsigned copy, 26 August 1953, Archives of Iowa Broadcasting History. Prospective television viewers in Waterloo did not learn of the agreement until September 2, when the Waterloo Courier reported that the FCC had announced KXEL's withdrawal of its application. The same day, DuMond and McElroy jointly announced the general terms of their agreeement. On October 5, the Courier reported McElroy's (accurate) prediction that Waterloo would have a VHF television station in operation by January 1 .

61. Waterloo Courier, 27 September 1953. 


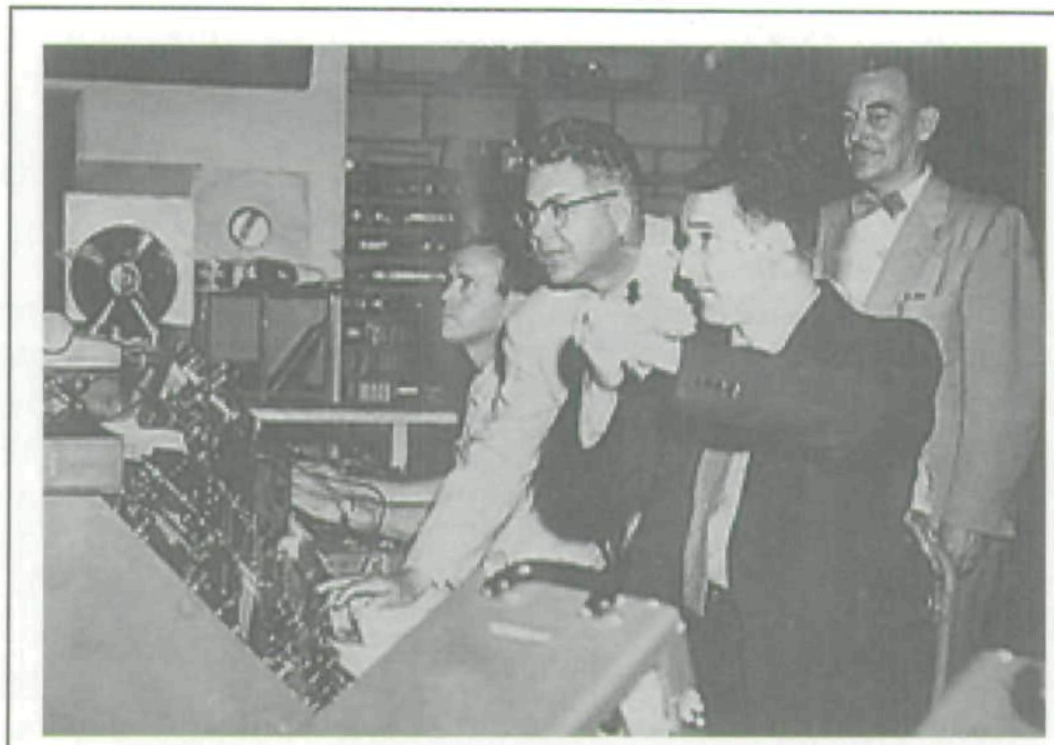

R. J. McElroy throws the switch putting Channel 7 on the air from the KXEL building. Courtesy Grout Museum of History and Science.

NOT SURPRISINGLY, the unusual cohabitation on US Highway 20 outside Waterloo was not a congenial relationship. As technicians began to install KWWL's television equipment, DuMond asked carpenters to erect a wall, completely dividing his building into two parts. On one side, KXEL continued operations in the radio studios and offices as it had for nearly a year. On the other side, KWWL employees began to learn how to operate the new medium of television, a primitive effort, according to Warren Mead, and an experience shared by fledgling television stations across the country at the time. Even as late as 1953, television was an unfamiliar and unexplored medium to many broadcasters, who had to learn firsthand the problems of programming, equipment, studio construction, and daily operation. "This, at first, was a sort of blind leading the blind operation," Mead wrote in his memoir of Black Hawk Broadcasting. "None of us knew anything about television or had ever worked in it. One or two of us attended workshops at WOI [at Iowa State College in Ames] but that was about the extent of formal train- 
ing. I was in charge of training news photographers on the doubtful basis that I had once been a relatively unsuccessful photographer." ${ }^{62}$

With DuMond's newly built wall epitomizing the hostility that permeated the license fight and the accord's failure to lay matters completely to rest, the landlord-tenant arrangement lasted less than five years. KWWL-TV vacated KXEL's building in 1958, moving both its radio and television operations into downtown Waterloo's Insurance Building, ironically the same building where Joe DuMond had started KXEL in 1942. DuMond sold KXEL to Egmont Sonderling, a suburban Chicago broadcaster, in 1955. In 1958 Sonderling, in turn, sold the station to Cy N. Bahakel, whose trust still owns the station today. ${ }^{63}$ The Josh Higgins persona, which had propelled an Iowa farm boy into prominence in the new world of broadcasting, was fading fast. DuMond cut most of his Iowa ties and moved with his family, first to Colorado, then in 1957 to Tucson, Arizona, where he re-entered broadcasting briefly as owner of KAIR radio. Shortly afterward, he sold the radio station and established a successful real estate business. He died in Tucson on November 30, 1990, nine days after his 92nd birthday. ${ }^{64}$

Before R. J. McElroy died unexpectedly on February 16, 1965, at age 54, he laid the foundation for what became a valuable corporate asset in the twelve years following his Channel 7 victory. He did so with a management style that perhaps reflected his impoverished childhood and earned him the reputation of a penny-pinching tyrant. As he struggled to keep his television station afloat with an undercapitalized company, McElroy cut all possible corners on anything that cost money. Aside from the studio cameras, Channel 7's entire inventory of camera equipment consisted of "one Bell and Howell $16 \mathrm{~mm}$ film camera ...., one $4 \times 5$ speed graphic and three black and

62. Mead, Black Hawk Broadcasting, 35; Sterling and Kittross, Stay Tuned, 258.

63. Al Laval to Kathryn Cole, 10 March 1969, Stations files (KXEL folder), Library of American Broadcasting; Federal Communications Commission, World Wide Web site, <http://www.fcc.gov/Bureaus/Mass_Media/Public_ Notices/Brdcst_Applications/ap990504.txt>, 18 March 2000.

64. Waterloo Courier, 6 December 1990. 
white polaroids. That was it, not only for news, but for the total operation," Warren Mead recalled. ${ }^{65}$

Perhaps worst of all was McElroy's management of people. With few exceptions, Mead and Falk among them, McElroy considered employees expendable. KWWL-TV's first weather reporter, Duane Hunting, had been an employee of Braniff Airlines and had studied meteorology. McElroy hired him to report the weather on both the 6:00 and 10:00 evening newscasts for $\$ 3.50$ per broadcast. "After a couple of years, I thought, 'I've got some experience, I should be in line for a raise, '" Hunting said. "Well, I tried for over two weeks to nail [McElroy] down to get an appointment, but he kept avoiding me. Finally, I did get a hold of him, and told him I really needed a raise. He said, 'Well, I believe at $\$ 3.50$ a show we could have one of our own people do it.' That was it. I was done. I didn't do another show." Another member of the staff was called in to present the weather report that night. Hunting's career as a television weather forecaster was over. ${ }^{66}$

Hunting was not alone. Over the years, hundreds of employees were cycled through McElroy's personnel system. Extreme as they were, McElroy's revolving-door employment practices were emblematic of the struggle that many small-market television stations faced in their early years. Audience size determined a station's advertising income, and established stations in large cities were more likely to become profitable in a shorter period of time than their newer counterparts in smaller markets. ${ }^{67}$ The FCC's 1952 table of channel assignments guaranteed for the first time the technical availability of channels in smaller markets, but it did not address the initial financial obstacles operators in those areas faced. ${ }^{68}$ In Waterloo, McElroy invested almost nothing in equipment during this early period, aside from a new, taller transmission tower.

65. Mead, Black Hawk Broadcasting, 35.

66. Duane Hunting, interview by Grant Price, Waterloo, 1998, videotape recording, Archives of Iowa Broadcasting History.

67. Sterling and Kittross, Stay Tuned, 258.

68. Ibid., 305. 
By the 1960s, however, television stations in most markets, including the smaller ones, had become profitable enterprises. Iowa's first commercial stations, WOC-TV in Davenport and WOI-TV in Ames, moved into new facilities with modern technology. KWWL-TV, however, remained poorly equipped. Not surprisingly, it languished in audience ratings, far behind its main competitor, CBS affiliate WMT-TV in Cedar Rapids, despite KWWL's affiliation with NBC, a network competitive with CBS during the 1950s and 1960s. ${ }^{69}$

The increasingly sophisticated television industry demanded greater competitiveness, and McElroy seemed to lack the necessary vision to achieve that. He did, however, know a bargain when he saw one. In October 1958 Black Hawk Broadcasting acquired KMMT-TV in Austin, Minnesota, a station on the verge of bankruptcy, and itself the object of a bitter license application dispute several years before. The acquisition was the first of several outside the Waterloo area for the growing company. ${ }^{70}$

McElroy especially savored his success in light of his humble beginnings and his yearning to become a part of Waterloo's civic leadership. Acceptance did not come easily for the roughhewn McElroy, however, who was self-conscious about his lack of a high school diploma. "He couldn't get elected to the Chamber of Commerce," recalled W. Louis Beecher, a friend and member of Black Hawk Broadcasting's board of directors. "He laid it to the fact that he was kind of a rough uncouth Irishman. ... They'd tolerate him but they weren't going to embrace him. That bothered [Robert] Buckmaster and myself." Beecher, as chairman of the Waterloo Chamber of Commerce, learned from reading its articles of incorporation that he was empowered to appoint board members under special circumstances. "So we went over to see McElroy and told him Beecher will appoint you if you'll accept it. He said, 'That's a heck of a way to get on the Board but I want on it.' . . . He turned out to be one of our best members," Beecher said. A 1963 study of Waterloo's power

69. "NBC Swamps Competition in Color," Weekly Television Digest 5, 29 November 1965,4 .

70. 1959 Broadcasting Yearbook (New York, 1959), B-46. 
structure ranked McElroy among Waterloo's 15 most influential citizens. $^{71}$

When McElroy died in 1965, the attorney who had helped him execute the coup for the Channel 7 license became the company's new president. Robert Buckmaster, an original investor and member of KWWL's board of directors, was, like McElroy, strong-willed, but he also understood the need to make his station competitive in the Waterloo-Cedar Rapids-Dubuque television market. To accomplish that he invested resources in personnel and equipment, setting a management course that, over the next 15 years, would make KWWL-TV's audience ratings first in its market. When Buckmaster assumed management of KWWL-TV in 1965, WMT-TV's newscasts usually attracted six to seven times as many viewers. By 1979, however, KWWLTV's 6:00 and 10:00 p.m. newscast ratings had surpassed WMTTV's, and Channel 7 has held first place in those two time periods ever since. ${ }^{72}$

Black Hawk Broadcasting's growth continued with the addition of KTIV television in Sioux City and radio stations in Cedar Rapids and Des Moines. In 1980, when it was sold to the broadcast division of AFLAC, Inc., a Georgia-based insurance company, Black Hawk Broadcasting consisted of three television and six radio stations, with some non-broadcast businesses. The corporation was sold for $\$ 40$ million, one thousand times the value of tiny, upstart KWWL radio, which McElroy had started in 1947, just 33 years before. "I am sure that we have grown far past any expectations that Mac ever had," Buckmaster said in 1977, three years before the company's sale. "Although much of this growth has come [since 1968], none of it would have been possible without him. His remarkable combination of intelligence, vision and pure guts weathered the op-

71. W. Louis Beecher, interview by Grant Price, Waterloo, 5 June 1996, videotape recording, Archives of Iowa Broadcasting History; Paul James Porter, "Decision Makers: A Study of the Power Structure of a Mid-Western Industrial Community" (master's thesis, State College of Iowa, Cedar Falls, 1963), 43.

72. Statistics were recorded from A. C. Nielsen Co. and Arbitron audience surveys by coauthor Grant Price, an employee of WMT-TV at the time. Black Hawk Broadcasting Company Papers, Archives of Iowa Broadcasting History. 
eration through storms that never could have been navigated by anyone else." ${ }^{73}$

Whatever McElroy achieved in business would be eclipsed by the legacy of his estate. The poor boy from Wisconsin who did not graduate from high school would encourage and support the education of thousands of young Iowans with a sixword phrase in his will. It stipulated that, after provision had been made for his family, the balance of his estate was to be used "for the benefit of young people." The will placed the responsibility for administering the estate in the hands of a trust, which Buckmaster managed from its inception until his death in 1993. The exponential increase in the value of the original Black Hawk stock created a large investment base for the McElroy Trust, which was converted to a tax-exempt foundation. In accordance with McElroy's wishes, much of the investment income has funded scholarships for high school and college students and grants to educational institutions. In addition, many human service and cultural organizations that serve young people have benefited from grants awarded by the trustees. By the end of 1998 , the foundation, valued at $\$ 49.5$ million, had disbursed over \$29 million in scholarships and grants.

THOSE who established television stations in the early 1950s faced an uncertain future, but they expected to make money despite the costs, risks, and untested nature of the new industry. By late 1953, as the backlog of contested applicants began to recede, new stations were signing on at the rate of one per day in the United States. ${ }^{74}$ In one sense, the Waterloo experience was typical of those cities for which contested hearings were imminent: two stubborn, yet starkly different men faced off in their home town, which hosted two fiercely competing radio stations and only one available television channel. In another sense, however, Waterloo's experience was unique: the quarrel never received a federal hearing.

73. Robert Buckmaster quoted in Mead, Black Hawk Broadcasting, 43-44.

74. "Log of Operating and Upcoming Stations," Television Digest 9, 12 September 1953 . 
Ironically, the FCC, chaired by a friend of Joe DuMond's, never considered DuMond's license application. Rather, in his zeal to win a license, DuMond violated a federal law and an FCC rule designed to protect his interests. KXEL-TV probably would have come to fruition if DuMond had acted properly by simply filing his application and allowing it to wend its way through the regulatory process. Instead, his zealous actions brought him to court and shattered his dream of being the one to bring television to the town where he had-started his broadcasting career. Perhaps DuMond's consolation was that television service did arrive in Waterloo sooner rather than later. 
Copyright of Annals of Iowa is the property of State of Iowa, by \& through the State Historical Society of Iowa and its content may not be copied or emailed to multiple sites or posted to a listserv without the copyright holder's express written permission. However, users may print, download, or email articles for individual use. 